\title{
OPEN Publisher Correction: Moisture transverse moving mechanism during presteamed oak lumber drying
}

\author{
Chengyuan Li®, Chun-Won Kang \& Xue-Feng Zhao
}

Correction to: Scientific Reports https://doi.org/10.1038/s41598-019-54430-5, published online 03 December 2019

The original version of this Article contained an error in the order of the Figures, where Figures 1, 2, 3 and 4 were published as 3, 4, 2 and 1 respectively. The figure legends were listed in the correct order at time of publication.

This has now been corrected in the HTML and PDF versions of this Article.

\begin{abstract}
(c) (i) Open Access This article is licensed under a Creative Commons Attribution 4.0 International License, which permits use, sharing, adaptation, distribution and reproduction in any medium or format, as long as you give appropriate credit to the original author(s) and the source, provide a link to the Creative Commons licence, and indicate if changes were made. The images or other third party material in this article are included in the article's Creative Commons licence, unless indicated otherwise in a credit line to the material. If material is not included in the article's Creative Commons licence and your intended use is not permitted by statutory regulation or exceeds the permitted use, you will need to obtain permission directly from the copyright holder. To view a copy of this licence, visit http://creativecommons.org/licenses/by/4.0/.
\end{abstract}

(C) The Author(s) 2020 